\title{
Mangrove forests in a peri-urban setting: the case of Mombasa (Kenya)
}

\author{
Mohamed Omar Said Mohamed · Griet Neukermans • \\ James Gitundu Kairo · Farid Dahdouh-Guebas • \\ Nico Koedam
}

Received: 28 November 2007 / Accepted: 3 June 2008/Published online: 28 June 2008

(C) Springer Science+Business Media B.V. 2008

\begin{abstract}
The structure and regeneration patterns of the peri-urban mangrove vegetation of Mombasa at Tudor creek were studied along belt transects at two forest sites of Kombeni and Tsalu. Based on the species importance values, the dominant mangrove species were Rhizophora mucronata Lam. (Rhizophoraceae) and Avicennia marina (Forssk.) Vierh. (Avicenniaceae). Lumnitzera racemosa Willd., reported in an earlier floristic survey, was not encountered. Tree density varied from 1,264 trees $\mathrm{ha}^{-1}$ at Kombeni to 1,301 trees $\mathrm{ha}^{-1}$ at Tsalu and mean tree height was higher at the former site compared to the latter. The size-class structure at both
\end{abstract}

M. O. S. Mohamed (凹) · G. Neukermans ·

F. Dahdouh-Guebas · N. Koedam

Biocomplexity Research Focus, Laboratory of Plant

Biology and Nature Management, Mangrove Management

Group, Vrije Universiteit Brussel, Pleinlaan 2,

1050 Brussels, Belgium

e-mail: omar_mohamed_said@hotmail.com

M. O. S. Mohamed

Kenya Wildlife Service, Mombasa Field Research Station,

P.O. Box 82144-80100, Mombasa, Kenya

M. O. S. Mohamed · J. G. Kairo

Kenyan Marine and Fisheries Research Institute,

P.O. Box 81651-80100, Mombasa, Kenya

F. Dahdouh-Guebas

Département de Biologie des Organismes, Université

Libre de Bruxelles - ULB, Campus du Solbosch, CP 169,

Avenue F.D. Roosevelt 50, 1050 Brussels, Belgium localities showed the numerical dominance of small trees over larger trees. The spatial distribution pattern of adults and juveniles varied greatly between sites and showed a close to uniform pattern (Morisita's Index $\left.I_{\delta} \ll 1\right)$ for adult trees, but a tendency to clustered distribution $\left(I_{\delta} \gg 1\right)$ for juveniles. The present paper shows that unmanaged but exploited peri-urban mangroves are structurally stressed, having enlarged canopy gaps that are characterised by spatial and temporal site heterogeneity that influences regeneration, implying longer periods for canopy closure. Diversifying uses of mangrove products and establishing reserves as no cut zones with regulated harvesting will minimise canopy gap sizes, and promote conservation practices. The proposed management strategy shall boost the ecosystem resilience to both anthropogenic and natural stressors expected in the peri-urban setting in the long run.

Keywords Anthropogenic - Canopy gaps · Peri-urban $\cdot$ Regeneration

\section{Introduction}

Mangrove swamps are typical wetland ecosystems found in coastal deposits of mud and silt throughout the tropical and subtropical coasts. These ecosystems are currently estimated to cover 15.2 million hectares of the tropical shorelines of the world (Spalding et al. 
1997; FAO 2003, 2005), representing a decline from 18.8 million hectares of mangroves in 1980 (Alongi 2002; FAO 2005; Duke et al. 2007). As intertidal ecosystems, mangrove forests assure essential functions and services to coastal zones and to their plant, animal and human populations (Cannicci et al. 2008; Kristensen et al. 2008; Nagelkerken et al. 2008; Walters et al. 2008). Mangrove degradation over time has been recurrently documented (DahdouhGuebas and Koedam 2008; Ellison 2008), but unfortunately direct and indirect anthropogenic pressure persists. Diversion of freshwater flows, deteriorating water quality caused by pollutants and nutrients, over-harvesting for fuel-wood and timber as well as conversion into development activities like agriculture, aquaculture, mining, salt extraction and infrastructure all contribute to the degradation and deforestation of mangrove ecosystems (Saenger et al. 1983; Terchunian et al. 1986; Primavera 1995; Twilley et al. 1995; Mandura 1997; Ellison 1998; Dahdouh-Guebas et al. 2000, 2004, 2005; Valiela et al. 2001; Abuodha and Kairo 2001; Kairo et al. 2001; Taylor et al. 2003; Benfield et al. 2005; Duke et al. 2007). Climate change poses an additional threat (Gilman et al. 2008).

In Kenya, mangroves are well developed in many areas along the coastline, particularly in creeks, bays and estuaries. It is estimated that mangroves cover 52,980 ha in Kenya (Doute et al. 1981), though the Kenya Forest Service (Forest Department of Kenya 1983) estimates 64,426 ha. The bulk of these forests occur in Lamu (33,500 ha), with smaller forests in Kwale (8,800 ha), Kilifi (6,600 ha) and Mombasa (2,000 ha) (Doute et al. 1981). Traditionally, mangroves in Kenya have been used as a source of building poles and fuelwood (Kokwaro 1985; Dahdouh-Guebas et al. 2000). During the colonial period (before 1963), mangrove wood products formed major export commodities, and by $1950 \mathrm{~s}$, sale of mangrove products were ranked third in the national revenue generation (Rawlins 1957). Overexploitation led to a presidential ban on mangrove exports in 1982, however, harvesting for domestic market intensified in many parts of Kenya, leading to further overexploitation and subsequent degradation (Kairo 2001; Abuodha and Kairo 2001; Dahdouh-Guebas et al. 2000; Taylor et al. 2003; Dahdouh-Guebas and Koedam 2006a, b). It is estimated that $20 \%$ of the total mangrove forests in Kenya have been lost already (Abuodha and Kairo 2001). This raises concerns on the sustainability of mangrove resource utilisation especially because human migration into coastal zones is high. Coastal zones are currently estimated to provide living space for $60 \%$ of the world's population (World Resources Institute 1996; Sheppard 2001), and the dependence on mangroves by coastal fisherfolk is large (Walters et al. 2008).

The major problem facing the management of mangrove forests in Kenya is the lack of a management plan (Dahdouh-Guebas et al. 2000; Kairo et al. 2002b), with annual quotas for extraction decided on unspecified basis, and compounded with inadequately supervised extraction operations (Kairo 2001; Ferguson 1993). Peri-urban mangroves in particular, are under environmental stress due to over-harvesting for domestic fuelwood and industrial energy, human encroachment for housing and pollution (Gang and Agatsiva 1992; Munga et al. 1993; Rees et al. 1996; Mwaguni and Munga 1997; Taylor et al. 2003).

Mombasa, a peri-urban island area, is bounded by two main creeks namely Tudor and Port Reitz, with a population of 917,864 , an average population density of 3,111 persons per $\mathrm{km}^{2}$ and an annual growth rate of 3.6\% (GOK 2005). Kilindini Harbour, East Africa's principal modern deep-water seaport, is located in the entrance of the Port Reitz creek. In the period 1983-1993, the port of Mombasa and its adjacent waters experienced five tanker accidents spilling a total of 391,680 tonnes of oil (Abuodha and Kairo 2001; Taylor et al. 2003). A major spill in 1988 destroyed 10 ha of mangroves in Makupa (Abuodha and Kairo 2001; FAO 2005), and in 2005, 200 tons of crude oil were spilled, affecting 234 ha of mangroves in Port Reitz creek (Kairo et al. 2005). In addition, the Mombasa municipal waste contributes about 4369 ton/year of BOD, 3964 ton/year of suspended solids, 622 ton/year of nitrates and 94 ton/year of phosphates into the creeks in the form of raw sewage (Mwaguni and Munga 1997; Mwangi et al. 1999). This is in addition to coliform and Escherichia coli levels of $1800+$ per $100 \mathrm{ml}$ and up to $550 \mathrm{cfu}$ per $100 \mathrm{ml}$ respectively (Mwaguni and Munga 1997; Mwangi et al. 1999).

Little information exists on the status of peri-urban mangroves globally, and few studies have been 
conducted on the structure and regeneration status of peri-urban mangroves. Previous mangrove forest structural studies in Kenya were conducted on mangroves of Kiunga (Kairo et al. 2002b), Tana River (Bundotich 2007), Mida (Kairo et al. 2002a), and Gazi bay (Kairo 2001). Despite the importance of the peri-urban mangroves of Mombasa, the forest structure and regeneration status is unknown. Knowledge on vegetation structure and regeneration potential of a specific forest is a prerequisite to designing forestry directives like annual allowable cuts and designating specific harvesting areas (FAO 1994). Ultimately, structural assessment will contribute to the development of sustainable forest management plans (Holdridge et al. 1971; FAO 1994). This study was designed to assess the structural conditions of mangrove forests in Tudor creek and to compare with published data on other Kenyan mangrove forests in a different setting.

\section{Materials and methods}

Study area

Tudor creek (Fig. 1) bounds Mombasa island on the northwest and extends some $10 \mathrm{~km}$ inland. The creek has two main seasonal rivers, Kombeni and Tsalu, draining an area of $550 \mathrm{~km}^{2}$ (450 and $100 \mathrm{~km}^{2}$ respectively) with average freshwater discharge estimated at $0.9 \mathrm{~m}^{3} \mathrm{~s}^{-1}$ during the inter-monsoon long rains (cited in Nguli 2006). It has a single narrow sinuous inlet with a mean depth of $20 \mathrm{~m}$, that broadens out further inland to a central relatively shallow basin $(5 \mathrm{~m})$ fringed by a well-developed mangrove forest mainly composed of $R$. mucronata (Rhizophoraceae), A. marina (Avicenniaceae) and Sonneratia alba $\mathrm{Sm}$. (Sonneratiaceae). The basin has an area of $6.37 \mathrm{~km}^{2}$ at low water spring and $22.35 \mathrm{~km}^{2}$ at high water spring. Mangrove forests
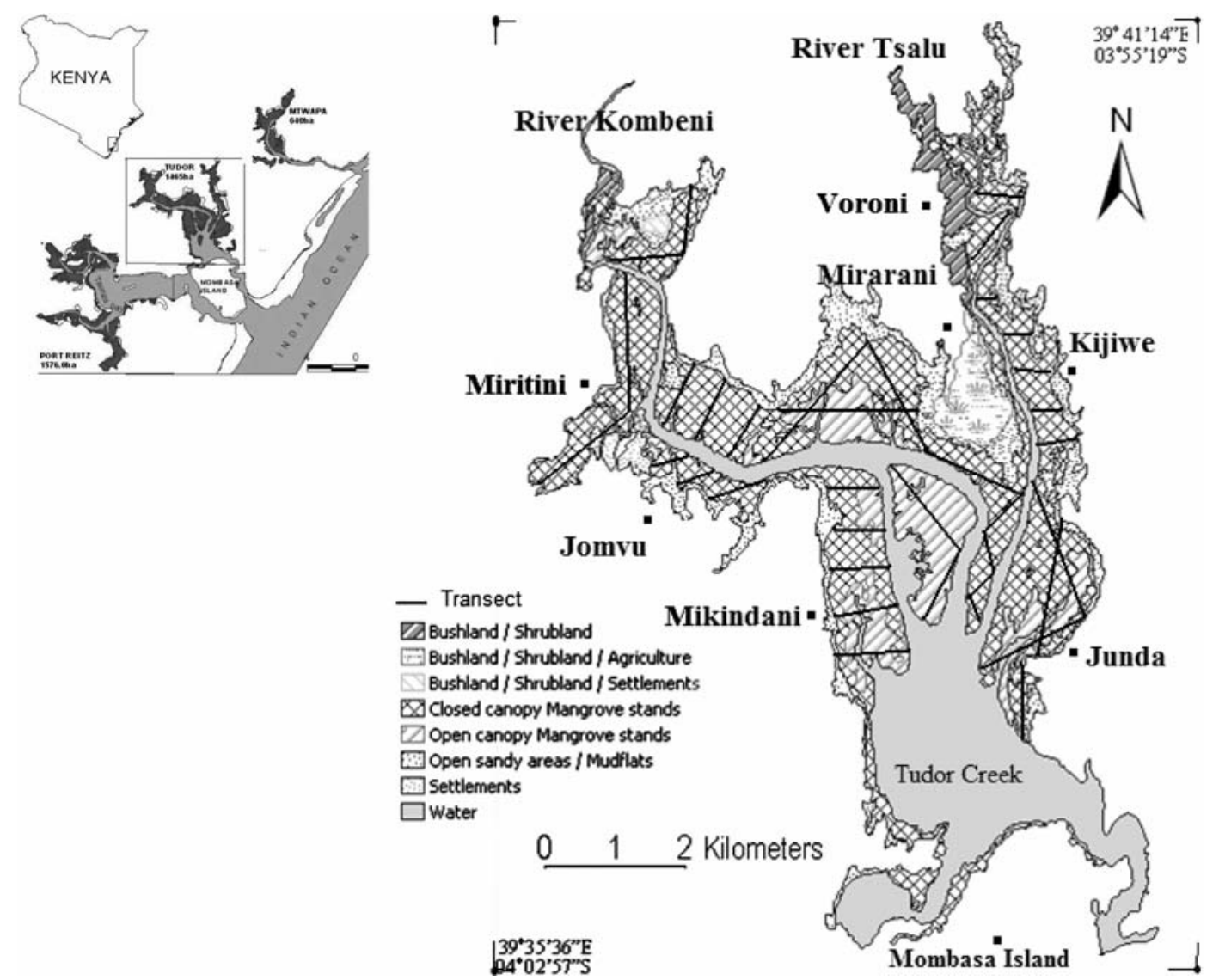

Fig. 1 Map of Mombasa showing the study area (Tudor creek) in relation to the other creeks (Source: DRSRS aerial photographs 2005) 
occupy $8 \mathrm{~km}^{2}$ of the creek. The floristic composition of mangroves of Tudor creek has been described by SPEK (1992). There is no obvious zonation displayed by the dominant mangrove species in Tudor creek. A. marina and Lumnitzera racemosa Wild. occupy the landward zone, whereas mostly a Ceriops tagal (Perr) C. B. Robinson and $R$. mucronata mosaic covers the middle zone. Wherever present, $S$. alba occupies the seaward margin, but is replaced by tall $A$. marina and $R$. mucronata along small creeks.

The forest resembles the fringing mangroves described by Lugo and Snedaker (1974), with strong inward tidal current during the flood tides which reverses during ebb tides, attaining maximum tide velocities of $0.6-0.7 \mathrm{~m} \mathrm{~s}^{-1}$ (Nguli 2006), and the dense, well-developed prop roots that accumulate large stocks of debris, with a spring tidal range of $3.5 \mathrm{~m}$ and a neap tidal range of $1.1-1.3 \mathrm{~m}$.

The mangroves of Tudor creek are separated naturally by two main tidal creeks, Kombeni and Tsalu, 4.5 and $3 \mathrm{~km}$ long respectively cutting through the mangroves connecting to the upstream rivers (Fig. 1). In the framework of this study these two tidal creeks were sampled separately and compared. Tsalu, the eastern tidal creek, includes mangroves near the rural villages of Mirarani, Voroni, Junda and Kijiwe. Kombeni, the western tidal creek, stretches between the cosmopolitan townships of Mikindani, Jomvu and Miritini. The creek is bordered by a steep cliff overlooking a tidal flat that extends to the mudflats occupied by the vast mangrove forest.

\section{Climate}

The climate of Mombasa is influenced by the semi annual passage of the inter-tropical convergence zone (ITCZ) and the monsoons. The North Easterly Monsoon (NEM) occurs from December to March, and the South Easterly monsoon from May to October. Most of the rainfall occurs between the monsoons when convention is enhanced. The mean annual rainfall is $1,038 \mathrm{~mm}$ with the months of April, May and June recording the maximum. Average annual temperatures for the two seasons are $23.9^{\circ} \mathrm{C}$ and $28.5^{\circ} \mathrm{C}$ respectively.

Forest structure and regeneration

A stratified sampling technique was used to sample mangroves of Tudor creek. The location of transect lines were determined by an initial reconnaissance and examination of medium-scale $(1: 25,000)$ panchromatic aerial photographs of the area. Belt transects of $10 \mathrm{~m}$ width were established both perpendicular and parallel to the creek across the entire forest in such a way that they represented as good as possible the general mangrove formation of Tudor creek (Fig. 1). Vegetation sampling was carried out within $100 \mathrm{~m}^{2}$ quadrats, established along the transects. A total of 106 and 124 plots were sampled in Kombeni and Tsalu respectively.

Within each quadrat, individual trees with but diameter greater than $2.5 \mathrm{~cm}$ were identified, counted and position marked. Vegetation measurements included tree height and stem diameter at $130 \mathrm{~cm}$ aboveground $\left(\mathrm{D}_{130}\right.$ sensu Brokaw and Thompson 2000, exceptions to this rule are described below), from which were derived tree basal area, stand density and frequency (Mueller-Dombois and Ellenberg 1974; Cintrón and Schaeffer-Novelli 1984). The ecological importance of each species was calculated by summing its relative density, relative frequency and relative dominance (Cintrón and SchaefferNovelli 1984). The complexity indices $\left(I_{\mathrm{c}}\right)$ of the forests were obtained as the product of number of species $(s p)$, basal area $\left(\mathrm{m}^{2} / \mathrm{ha}\right)(b a)$, maximum tree height (in $\mathrm{m}$ ) ( $h t$ ) and number of stems ha ${ }^{-1}$ (d) $\times 10^{-5}$ (Holdridge et al. 1971).

$$
\begin{aligned}
I_{\mathrm{c}}= & s p(\mathrm{n}) \times b a\left(\mathrm{~m}^{2} / \mathrm{ha}\right) \times h t(\mathrm{~m}) \times d(\mathrm{n} / \mathrm{ha}) \\
& \times 10^{-5}
\end{aligned}
$$

Stems with diameters below $2.5 \mathrm{~cm}$ were considered in the category "juveniles" (Kairo et al. 2002). Stumps were also counted in each quadrat as an indicator of anthropogenic pressure and tree mortalities.

Tree heights were measured in meters using a Suunto $^{\mathrm{TM}}$ hypsometer, whereas stem diameter was measured in centimetres using a forest calliper. For Rhizophora, stem diameters were measured $30 \mathrm{~cm}$ above the highest prop roots, whereas for Avicennia, when the stem forked below $130 \mathrm{~cm}$, individual 'branches' in a clump were treated as separate stems. Pole quality was assessed based on the form of the lead stem and assigned either form 1, 2 or 3. Form 1 stems denote those whose lead stem is straight and therefore excellent for construction but form 2 stems need slight modification to be used for construction. 
Poles which are unsuitable for construction were assigned form 3 (Kairo 2001).

Information on the composition and pattern of natural regeneration was obtained using the method of Linear Regeneration Sampling (Sukardjo 1987). In $5 \times 5 \mathrm{~m}^{2}$ subplots (within the main $10 \times 10 \mathrm{~m}^{2}$ quadrats), occurrence of juveniles of different species was recorded and grouped according to height classes. Seedlings less than $40 \mathrm{~cm}$ in height were classified as regeneration class I (RCI). Saplings between 40 and $150 \mathrm{~cm}$ height were classified as RCII, while RCIII was for all small trees with heights greater than $1.5 \mathrm{~m}$ but less than $3 \mathrm{~m}$. The analysis of spatial pattern of adults and juveniles in the field was carried out inside $10 \times 10 \mathrm{~m}^{2}$ plots along transects. The measure of dispersion used was Morisita's dispersion Index (Morisita 1959), the application of which is described in Greig-Smith (1983). Morisita's Index $\left(I_{\delta}\right)$ is:

$I_{\delta}=q \frac{\sum_{i=1}^{q} n_{i}\left(n_{i}-1\right)}{N(N-1)}$

where $q$ is the number of quadrats, $n_{i}$ is the number of individuals per species in the $i$ th plot, and $N$ is the total number of individuals in all $q$ quadrats. If $I_{\delta}>1$, the population is clustered, if $I_{\delta}=1$, the population is randomly dispersed and if $I_{\delta}<1$, the population is evenly dispersed. Socio-ecological information was obtained primarily from interviews conducted with mangrove harvesters, fishermen and Government Forestry Officers.

\section{Data treatment}

All data analysis and graphical presentation were obtained with the STATISTICA 8.0 program. Oneway ANOVA was performed on stocking densities of different size classes, which we assume as a measure of age. The relative density, dominance and frequency were estimated and the importance values established according to Dahdouh-Guebas and Koedam (2006).

Stand densities were harmonized using De Liocourt's negative exponential model (Clutter et al. 1983). According to the model, the ratio between the numbers of trees in successive diameter classes of uneven-aged stand is roughly constant for a particular forest, but varies from one forest to another. This has been confirmed in a number of uneven-aged forests throughout the world (see e.g. Clutter et al. 1983). De Liocourt's model applies particularly in mixed forests where the size classes and recruitment by natural regeneration are continuous. Supposing this is $q$, then the number of trees in successive diameter classes will be represented by a descending geometric sequence of the form $a q^{n}, a q^{n-1}, a q^{n-2}, a q^{n-3}, \ldots$, $a q^{3}, a q^{2}, a q^{1}, a$, where $a$ is the number of trees in the largest size class of interest and $n$ is the number of classes.

For such a geometric series, if the logarithm of the frequency in successive classes is plotted against size class, the distribution can be represented as an exponential curve of the form:

$y=k \mathrm{e}^{-a x}$

where $y$ is the number of trees in diameter class $x$; $e$ is the base of natural $\log$ (2.718) while $k$ and $a$ are constants estimated as:

$k=\frac{N}{\mathrm{e}^{-a d_{1}}}$

$a=\frac{1}{d_{2}-b}$

where $N=$ theoretical number of trees in the first size class; $d_{1}=$ middle value for the first size class; $b=$ stand diameter measurement threshold; and $d_{2}=$ mean stand diameter.

The constants $k$ and $a$ in the equation above vary between forests and site. Constant $k$ reflects the occurrence of seedling regeneration and tends to be large $N$ in forests containing prolific seed-bearing tree species, while $a$ determines the relative frequencies of successive diameter classes. A high $a$ is associated with high mortality between classes and is likely to occur in stands comprising light demanding (shade intolerant) tree species (Kairo et al. 2002).

The nature of the future forest was derived from the present forest by fitting exponential models to the size-class structures and comparing the results at a 0.05 significant level. Each class interval was considered to be independent and thus included as within-factor repeated measure variable during the analysis. Regeneration densities and ratios were calculated and the correlation with canopy gaps done using Spearman correlation. 


\section{Results}

Floristic composition

The structural characteristics of the mangroves of Tudor creek are given in Table 1. Six mangrove species were encountered during the survey. Based on the species' importance values, $R$. mucronata and A. marina were the principal species in both sites. Xylocarpus granatum Koen. (Meliaceae) was encountered in Tsalu only, while L. racemosa was not encountered despite earlier reports of its occurrence in the landward fringe (SPEK 1992). Relative dominance, density, frequency and importance values of these species are shown in Table 1.

\section{Stocking density}

Table 2 gives vegetation inventories for Tudor creek mangroves. There were 1,264 stems ha ${ }^{-1}$ of mangroves in Kombeni, out of which, $71.57 \%$ were R. mucronata, $11.42 \%$ S. alba and $11.34 \%$ A. marina.

Table 1 Structural attributes of the mangroves of Tudor creek, Kenya

\begin{tabular}{|c|c|c|c|c|c|c|c|c|c|c|}
\hline & \multirow[t]{2}{*}{ Species } & \multirow[t]{2}{*}{ Height (m) } & \multirow{2}{*}{$\begin{array}{l}\text { BA } \\
\left(\mathrm{m}^{2} \mathrm{ha}^{-1}\right)\end{array}$} & \multirow{2}{*}{$\begin{array}{l}\text { Density } \\
\left(\mathrm{ha}^{-1}\right)\end{array}$} & \multicolumn{3}{|l|}{ Relative } & \multirow[t]{2}{*}{ IV } & \multirow[t]{2}{*}{ Rank } & \multirow[t]{2}{*}{ CI } \\
\hline & & & & & Density & Dominance & Frequency & & & \\
\hline \multirow[t]{5}{*}{ Kombeni } & A. marina & $7.98 \pm 2.94$ & 7.07 & 143.40 & 11.34 & 43.43 & 24.53 & 79.30 & 2 & 4.38 \\
\hline & B. ${ }_{\text {gymnorrhiza }}^{\mathrm{a}}$ & $4.09 \pm 0.86$ & 0.15 & 16.98 & 1.34 & 0.91 & 5.66 & 7.91 & 5 & \\
\hline & C. tagal & $2.62 \pm 1.05$ & 0.16 & 54.72 & 4.33 & 1.00 & 10.38 & 15.70 & 4 & \\
\hline & R. mисronata & $3.61 \pm 2.10$ & 5.91 & 904.72 & 71.57 & 36.31 & 62.26 & 170.14 & 1 & \\
\hline & S. alba & $5.22 \pm 2.41$ & 2.99 & 144.34 & 11.42 & 18.36 & 12.26 & 42.04 & 3 & \\
\hline \multirow[t]{6}{*}{ Tsalu } & A. marina & $6.23 \pm 3.30$ & 5.89 & 167.74 & 14.60 & 60.69 & 25.00 & 100.29 & 2 & 2.60 \\
\hline & B. gymnorrhiza & $3.82 \pm 1.72$ & 0.17 & 29.84 & 2.60 & 1.71 & 8.06 & 12.37 & 4 & \\
\hline & C. tagal & $2.30 \pm 0.55$ & 0.58 & 175.81 & 15.30 & 5.99 & 29.84 & 51.13 & 3 & \\
\hline & R. mucronata & $3.00 \pm 1.06$ & 2.58 & 750.00 & 65.26 & 26.57 & 83.87 & 175.70 & 1 & \\
\hline & S. alba & $5.09 \pm 2.09$ & 0.39 & 20.97 & 1.82 & 4.00 & 3.39 & 9.21 & 5 & \\
\hline & $X$. granatum & $3.83 \pm 0.68$ & 0.10 & 4.84 & 0.42 & 1.05 & 1.61 & 3.08 & 6 & \\
\hline
\end{tabular}

${ }^{a}$ Bruguiera gymnorrhiza (L.) Lam

Table 2 Stand table for the mangrove forest of Tudor creek

\begin{tabular}{|c|c|c|c|c|c|c|c|c|}
\hline \multirow[t]{2}{*}{ Site } & \multirow[t]{2}{*}{ Species } & \multicolumn{6}{|c|}{$\mathrm{D}_{130}$ class $(\mathrm{cm})$} & \multirow{2}{*}{$\begin{array}{l}\text { Density } \\
\left(\text { stems ha }^{-1}\right)\end{array}$} \\
\hline & & 6 & $6.1-9$ & $9.1-13$ & $13.1-20$ & $20.1-35$ & 35 & \\
\hline \multirow[t]{6}{*}{ Kombeni } & A. marina & $2(1.32)$ & $11(7.89)$ & $15(10.53)$ & $33(23.03)$ & $68(47.37)$ & $14(9.87)$ & $143(11.34)$ \\
\hline & B. gymnorrhiza & $8(44.44)$ & $4(22.22)$ & $2(11.11)$ & $4(22.22)$ & - & - & $17(1.34)$ \\
\hline & C. tagal & $36(65.52)$ & $16(29.31)$ & $2(3.45)$ & $1(1.72)$ & _ & - & $55(4.33)$ \\
\hline & R. mucronata & $607(67.05)$ & $131(14.49)$ & $69(7.61)$ & 63 (6.99) & $28(3.13)$ & $7(0.73)$ & 905 (71.57) \\
\hline & S. alba & $24(16.34)$ & 25 (16.99) & $35(24.18)$ & $38(26.14)$ & $20(13.73)$ & $4(2.61)$ & $144(11.42)$ \\
\hline & Total & $675(53.43)$ & $187(14.78)$ & $123(9.70)$ & 139 (10.97) & $116(9.18)$ & $25(1.94)$ & 1264 \\
\hline \multirow[t]{7}{*}{ Tsalu } & A. marina & $15(8.65)$ & $20(12.02)$ & $24(14.42)$ & $39(23.08)$ & $60(36.06)$ & $10(5.77)$ & $168(12.90)$ \\
\hline & B. gymnorrhiza & $17(56.76)$ & $9(29.73)$ & $2(5.41)$ & $2(5.41)$ & $1(2.70)$ & - & $30(2.29)$ \\
\hline & C. tagal & $123(69.72)$ & $34(19.27)$ & $15(8.72)$ & $4(2.29)$ & - & - & $176(13.52)$ \\
\hline & R. mисronata & $590(78.60)$ & $113(15.05)$ & $23(3.01)$ & $16(2.15)$ & $9(1.18)$ & _ & $750(57.66)$ \\
\hline & S. alba & $3(15.38)$ & $6(30.77)$ & $5(23.08)$ & $3(15.38)$ & $3(15.38)$ & - & $21(1.61)$ \\
\hline & X. granatam & $2(1.26)$ & $42(32.70)$ & $16(12.58)$ & $30(23.27)$ & $34(26.42)$ & $5(3.77)$ & $128(9.68)$ \\
\hline & Total & $748(57.53)$ & $224(17.23)$ & $85(6.51)$ & 94 (7.19) & $107(8.25)$ & 43 (3.29) & 1301 \\
\hline
\end{tabular}

Values in parentheses indicate percentage of the total stem density per class per species, and the totals 
While there was 1,301 stems ha $^{-1}$ of mangroves in Tsalu, of which $57.66 \%$ were $R$. mucronata, $13.52 \%$ C. tagal and $11.34 \%$ X. granatum. The variation in complexity index between Kombeni and Tsalu is evident (Table 1), with Kombeni recording a higher index than Tsalu.

Figure 2 shows scattergrams of heights against stem diameters of mangrove forests in Tudor creek. There were significant differences in height $\left(F_{(1,2763)}=\right.$ $86.765 ; P=0.0001)$ and stem diameter $\left(F_{(1,2763)}=\right.$ $36.727 ; P=0.0001$ ) between the tidal creeks. $53.43 \%$ and $57.53 \%$ trees in both Kombeni and Tsalu respectively, were in the lower size class (below $6.0 \mathrm{~cm}$ ). $A$. marina was characterised by low densities of tree in the lower size class (2-5\%; Table 3 ), and high densities of trees in the medium size class $(33.55-50.33 \%)$. The case of $S$. alba was similar to A. marina, being that the effect of selective harvesting has resulted in a relative redistribution of stems to mid-size classes. The observed trends in stem size distributions can be attributed to selective harvesting, which has preference for $R$. mucronata. The general quality of the standing wood quantity in the two locations was dominated by
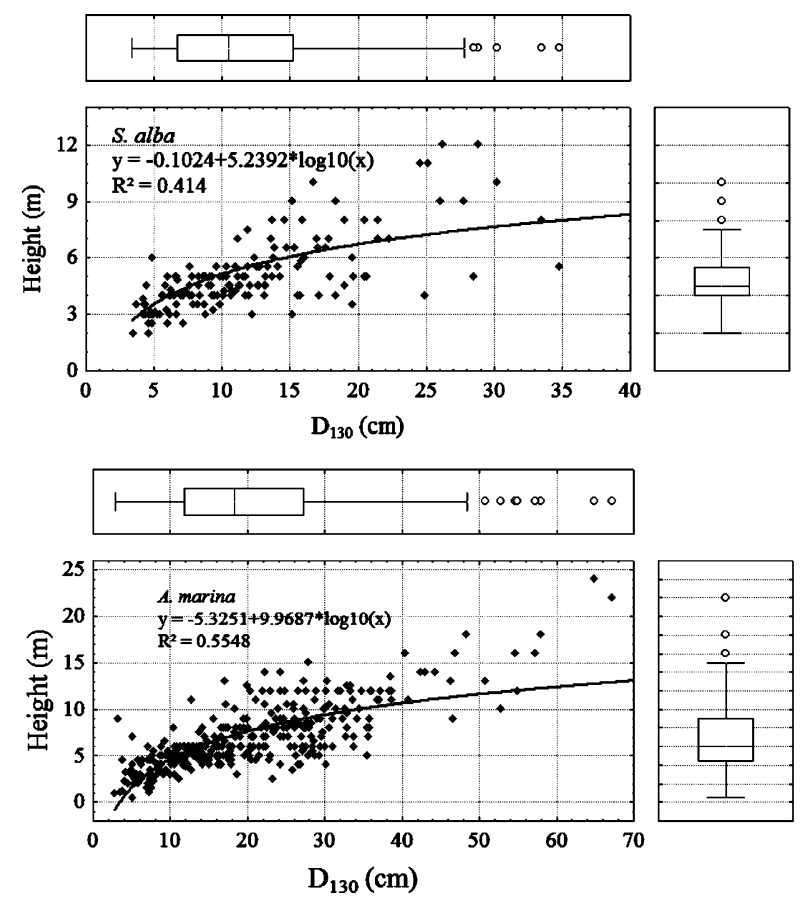

Fig. 2 Scattergrams of height vs. $\mathrm{D}_{130}$ distributions of $R$. mucronata, A. marina, C. tagal and S. alba for Tudor creek mangroves. The equation, correlation coefficients $\left(R^{2}\right)$, $(P<0.05)$ are given in each case. The box plots display
Table 3 Tree form distributions in Tudor creek showing the densities per ha and percentages (in brackets) composition per species

\begin{tabular}{lcrr}
\hline Form & 1 & \multicolumn{1}{l}{} & \multicolumn{1}{l}{3} \\
\hline A. marina & - & $16(11.05)$ & $124(88.67)$ \\
B. gymnorrhiza & $2(9.80)$ & $7(33.33)$ & $11(56.86)$ \\
C. tagal & $7(8.61)$ & $42(52.15)$ & $32(39.23)$ \\
R. mucronata & $24(3.42)$ & $283(40.23)$ & $396(56.35)$ \\
S. alba & - & $28(40.57)$ & $40(59.43)$ \\
Total & $33(3.30)$ & $375(37.05)$ & $603(59.66)$ \\
\hline
\end{tabular}

the crooked tree form (Table 3). No significant differences were found in cutting intensity between sites (Mann-Whitney $U$ test, $Z=-1.26192, P=$ 0.206979), but stump densities were slightly higher in Tsalu (4,359 stumps ha $\left.{ }^{-1}\right)$ than in Kombeni (4,167 stumps ha $\left.{ }^{-1}\right)$.

\section{Regeneration}

Significant differences in juvenile densities were observed across the study area. On average the
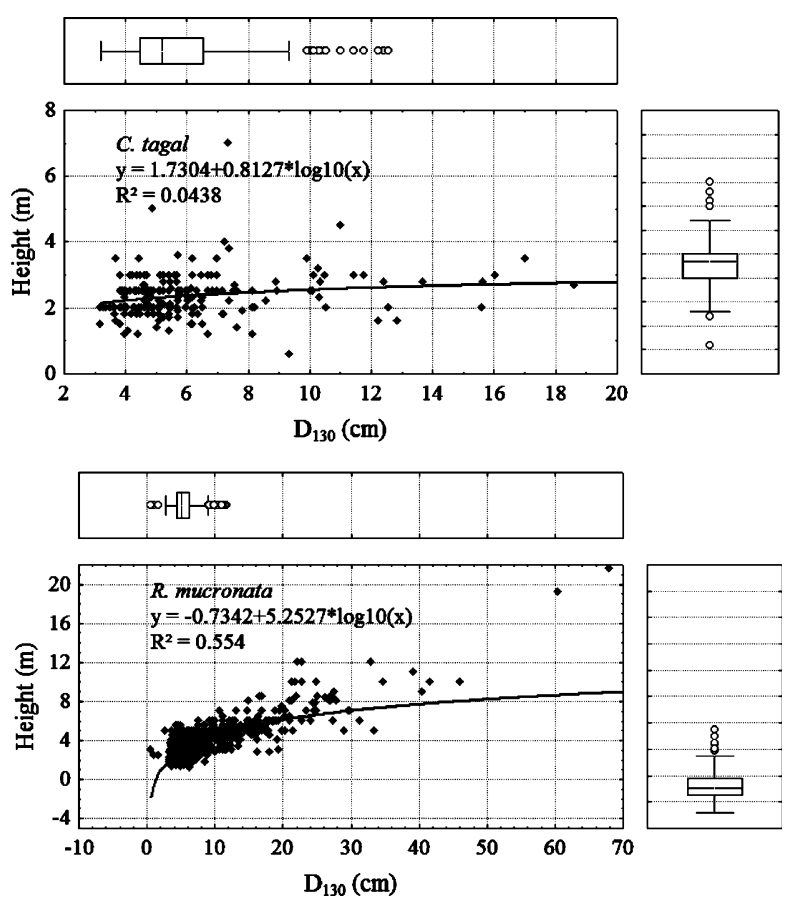

percentile distribution in each case. The extremities of the plot correspond to the maximum and the minimum observations in the data set. The ends of the box are positioned at the 25th and 75th percentiles of the data set 
juvenile densities were in the range 21,905$33,965 \mathrm{ha}^{-1}$, with $R$. mucronata representing approximately $45-75 \%$ of the total juveniles (Table 4). Examination of dispersion pattern showed a tendency towards a random distribution $\left(I_{\delta} \ll 1\right)$ of adult trees, but a clustered distribution for juveniles $\left(I_{\delta}>1\right)$ (Table 5). There was a significant negative correlation between open canopy and seedling density per sampled plot $(N=141 ;$ Spearman $=-0.373086$; $t(N-2)=-4.74094 ; P=0.000005$; Fig. 3), which together with the proximity to the mother plant and altered environmental gradients in gaps (Clarke 2004), could have contributed to the clumped distribution of seedlings.

Very few saplings were observed for S. alba. The equivalent regeneration ratios i.e. RCI:RCII:RCIII were 4:1:1 for Kombeni and 1:1:2 for Tsalu. The

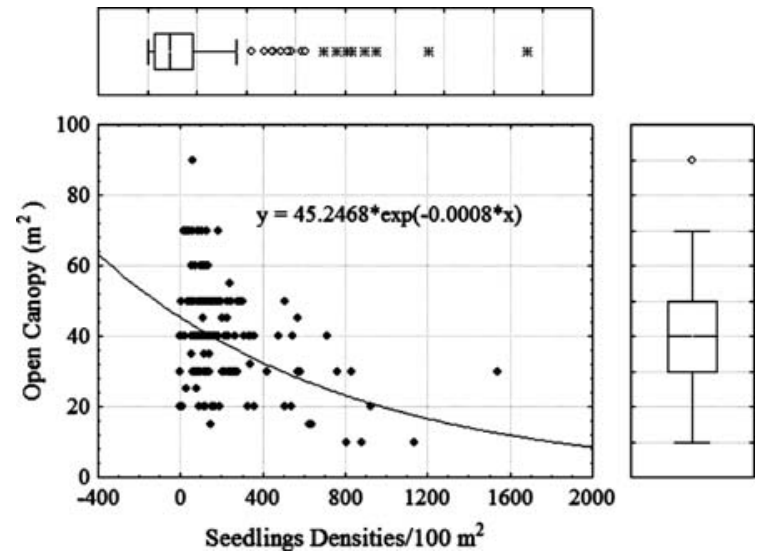

Fig. 3 Scattergrams of open canopy vs. regeneration densities. The box plots display percentile distribution in each case. The ends of the box are positioned at the 25th and 75th percentiles of the data set
Table 4 Juveniles density (saplings $\mathrm{ha}^{-1}$ ) in Tudor creek

Values in parentheses indicate percentages

Table 5 Morisita Index in relation to distance from the creek for juvenile $R$. mucronata and A. marina

The distribution shows a tendency towards clustering. There is a distinct zonation pattern, with A. marina in the landward and seaward sides and $R$. mucronata in the mud flats

\begin{tabular}{|c|c|c|c|c|c|}
\hline Site & Species & $\begin{array}{l}\text { RCI } \\
0-40 \mathrm{~cm}\end{array}$ & $\begin{array}{l}\text { RCII } \\
40.1-150 \mathrm{~cm}\end{array}$ & $\begin{array}{l}\text { RCIII } \\
150.1-300 \mathrm{~cm}\end{array}$ & Total ha ${ }^{-1}$ \\
\hline \multirow[t]{7}{*}{ Kombeni } & A. marina & $17,080(99.70)$ & $37(0.22)$ & $15(0.09)$ & $17,132(50.46)$ \\
\hline & B. gymnorrhiza & $60(33.90)$ & $81(45.76)$ & $37(20.90)$ & $177(0.52)$ \\
\hline & C. tagal & $271(25.78)$ & $411(39.11)$ & $368(35.01)$ & $1,051(3.10)$ \\
\hline & R. mucronata & $4,357(27.94)$ & $4,802(30.80)$ & $6,432(41.25)$ & $15,592(45.92)$ \\
\hline & S. alba & - & - & 1 & $1(0.00)$ \\
\hline & $X$. granatum & - & - & - & $-(0.01)$ \\
\hline & Total ha ${ }^{-1}$ & $21,768(64.11)$ & $5,331(15.70)$ & $6,853(20.18)$ & 33,953 \\
\hline \multirow[t]{7}{*}{ Tsalu } & A. marina & $2,234(93.28)$ & $78(3.26)$ & $82(3.42)$ & 2,395 (11.09) \\
\hline & B. gymnorrhiza & $318(81.54)$ & 47 (12.05) & $25(6.41)$ & $390(1.81)$ \\
\hline & C. tagal & $1,251(38.15)$ & $870(26.53)$ & $1,158(35.32)$ & $3,279(15.18)$ \\
\hline & R. mucronata & $3,713(23.95)$ & $4,066(26.22)$ & $7,725(49.82)$ & $15,505(71.77)$ \\
\hline & S. alba & - & - & - & - \\
\hline & $X$. granatum & $34(91.89)$ & $2(5.41)$ & - & $37(0.17)$ \\
\hline & Total $\mathrm{ha}^{-1}$ & $7,550(34.95)$ & $5,064(23.44)$ & $8,991(41.62)$ & 21,605 \\
\hline
\end{tabular}

\begin{tabular}{llllllll}
\hline & Site & Species & \multicolumn{7}{c}{ Distance from creek (m) } \\
\cline { 3 - 8 } & & & 10 & 50 & 100 & 150 & 200 \\
\hline \multirow{2}{*}{ Kombeni } & \multirow{2}{*}{ Mikindani } & A. marina & 0.0005 & - & - & - & - \\
& & R. mucronata & 1.25 & 0.52 & 0.45 & - & - \\
& \multirow{4}{*}{ Jomvu } & A. marina & 17.4 & - & - & - & - \\
& \multirow{4}{*}{ Julu } & R. mucronata & 0.01 & 0.07 & 0.07 & - & - \\
& \multirow{4}{*}{ Munda } & A. marina & 0.066 & - & - & - & - \\
& & R. mucronata & 3.32 & 6.41 & 1.62 & 0.017 & 0.016 \\
& & A. marina & 0.0001 & 2.60 & - & 0.0028 & - \\
& & R. mucronata & 0.1126 & 8.09 & 2.18 & 0.056 & 0.003 \\
\hline
\end{tabular}


regeneration ratios are not within the range of effective stocking rate 6:3:1 for saplings described by Chong (1988). However, Tudor creek mangroves can still be considered potentially of good regeneration capacity taking into account the seedling densities.

\section{Discussion}

Vegetation structure

The mangroves of Tudor creek are not prestine, and are recipient of significant anthropogenic pressure, probably resulting in losses of species such as $L$. racemosa by an observed silted landward fringe amongst others. Anthropogenic influences such as indiscriminate and unregulated harvesting, raw industrial and domestic sewage pollution and enhanced siltation have had accumulated effects on the structure and regeneration of the forest, which is characterised by high density of stumps and a dominant crooked tree form. However, the impacts of raw domestic sewage cannot be proven from current observations, but studies indicate enhanced mangrove growth rates (Feller et al. 2003; Boonsong et al. 2003), with no apparent negative effects (Wong et al. 1997; Vaiphasa et al. 2007). The complexity index, an indicator of the overall structural development of a forest stand, was low compared to observations along the Kenyan coast (Kairo 2001; Kairo et al. 2002; Bosire et al. 2003; Bundotich 2007), an indication of a dominant young vegetation, with low basal area and height.

The structural characteristics of Tudor creek mangroves are given in Table 2. Generally, the stand density is lower for large trees, which is to be expected, and diminished for the stem diameter range $6-13 \mathrm{~cm}$ and $6-20 \mathrm{~cm}$ for Kombeni and Tsalu respectively, implying higher harvests in a rural setting. Theoretically, in an uneven-aged forest there is a normal series of age-gradations, depicted by the reversed $\mathbf{J}$ curve. This relation in size classes is not observed for Tudor creek, and when put into sizefrequency diagrams it is not possible to obtain a simple correlation between size classes and densities (Fig. 4), an indication of man-induced influences in the forest. It indicates a forest disturbance regime according to direct needs by the people, lacking a
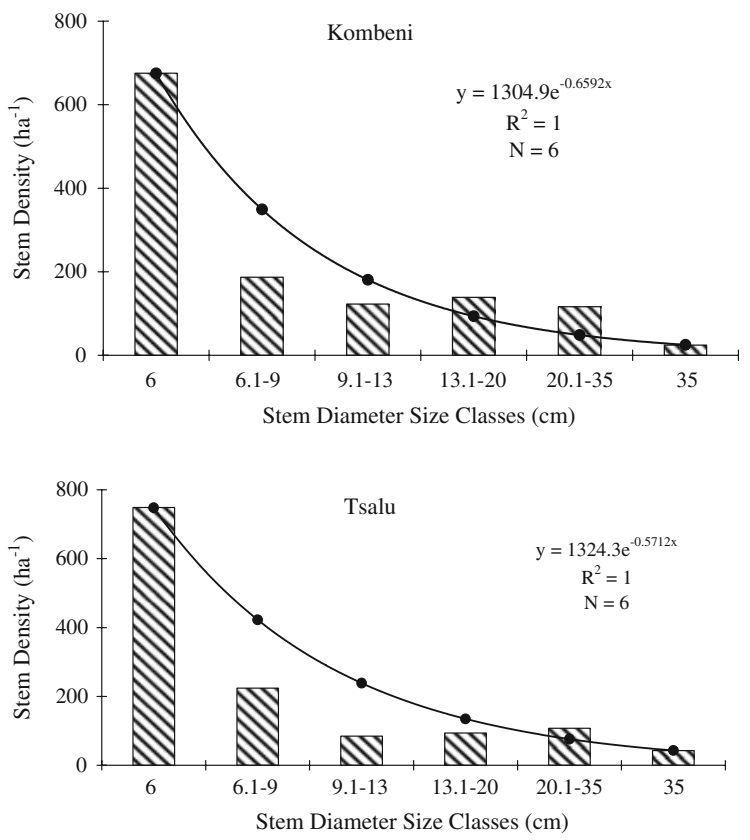

Fig. 4 Observed (bars) and predicted (curve) size class distribution of mangrove forests of Tudor creek. A high ' $k$ ' value in the stand curve $y=k \mathrm{e}^{-a x}$ for Kombeni and Tsalu reflects the occurrence of sporadic natural regeneration in the forest

consistent harvesting plan, resulting in a haphazard spatial distribution of different size classes, with a highly selective graphical frequency distribution. Assuming that tree size express age, we can use the density curves obtained in this study (Fig. 4) to predict the composition of the future managed forest. This can be done by harmonizing the irregularities in the stem size distribution by harvesting 'excess' trees in those size-classes observed densities are higher than expected and in the long run, allow multiple uses of mangrove wood that will reduce stem density per class.

\section{Regeneration}

Natural regeneration was observed all over the creek, with $R$. mucronata seedlings and saplings dominating, while A. marina seedlings were abundant, with low density of saplings, implying high mortality of seedlings and/or saplings resulting in low recruitments into successive regeneration classes. C. tagal, $B$. gymnorrhiza and $X$. granatum had very low regeneration levels, with $S$. alba having particularly low regeneration, with the adults visibly impacted by 
insects, and in some areas suffering die backs, a fact reported in 1992 (SPEK 1992) and observed in this study. Observations indicate regeneration based on the "direct replacement" model, with species replaced by members of the same species as reflected by stand composition, but establishment and survival is diminished due to site spatial and temporal heterogeneity introduced by canopy gap formation and siltation (Flower and Imbert 2006).

In this study, we observed high abundance of juveniles in smaller gaps and under canopies than in larger gaps (Fig. 3). Clarke and Kerrigan (2000) and Minchinton (2001) reported the impacts of canopy size on regeneration. They cited an extremely local dispersal of propagules, coupled with habitat heterogeneity due to disturbance and altered topography as the causes of altered regeneration in large canopy gaps. In Tudor creek, harvesting has enlarged canopy gaps, while siltation has altered edaphic conditions, causing habitat heterogeneity and altered topography, impacting on propagule dispersal, establishment, survival and growth. This scenario is unsustainable, implying inadequate regeneration, altered forest growth and longer times for canopy gap closure as a result of limiting conditions within large canopy gaps (Clarke and Kerrigan 2000; Clarke 2004). Dominance of $R$. mucronata can be linked to the larger propagule mass, which allows it withstand siltation, compared to the smaller seeds of the other species (Mohamed's personal observation). In addition, enhanced predation of dispersed propagules confers advantages to propagules of species that are local canopy members, limiting the range of species available to fill the gaps (Osborne and Smith 1990; Clarke and Kerrigan 2002; Bosire et al. 2005).

\section{Implications}

Forest canopy gaps are common in mangroves and usually result after disturbances such as selective harvesting and natural mortality of trees (Duke 2001). Canopy gaps drive the gap phase regenerative cycles in mangrove forests (Clarke and Kerrigan 2000; Duke 2001; Imai et al. 2006; López-Hoffman et al. 2007). The gap creation frequency in Tudor creek is high, stimulating regeneration that approximates selection forest working, favouring R. mucronata (FAO 1994; Ewel et al. 1998; Clarke and Kerrigan 2000; Duke
2001). However, regenerative turnover might have overwhelmed progress in stand development, causing forest growth reversal resulting in a relatively young forest (Duke 2001), as older trees have either been selectively harvested or impacted by silt. Siltation, though not systematically studied, causes mortality of both adults and juveniles, through inhibition of gaseous exchange of roots causing root damage, oxygen deficiency and eventually reduced vigour (Ellison 1998; Thampanya et al. 2002).

Gaps are generally characterised by increased light and temperature, high soil evaporation rates with high transpiration rates from trees surrounding the gaps, and high pore-water salinities (Ewel et al. 1998; Duke 2001; Alongi and de Carvalho 2008). They alter propagule predation by crabs (Osborne and Smith 1990; Clarke and Kerrigan 2002; Bosire et al. 2005), reduce proportion of reproductive trees ('propagule limitation') and diminish soil stability (Ewel et al. 1998; Clarke and Kerrigan 2000; Kairo 2001). It has been observed that natural gap formation induces less severe physical and chemical changes than caused by human disturbances (Clarke and Kerrigan 2000; Duke 2001), resulting in lowered regeneration and development rates under human disturbances (Allen et al. 2001; Duke 2001). In our observation, larger gaps are likely to have more diverse physico-chemical gradients, especially in Mombasa, characterised with a pronounced dry season, manifested by dramatic vegetation responses. This is in contrast to high rainfall areas, lacking distinct wet or dry season, with a buffering effect of freshwater input (Ewel et al. 1998; Pinzón et al. 2003).

Gaps created by selective harvesting of branches recover over long periods (Ellis and Bell 2004), with the extent of recovery governed in part, by the regenerative capabilities of the damaged mangrove species and the nature and severity of the causative agent (Snedaker et al. 1992; Ellis and Bell 2004). In contrast to species such as A. marina, which hold reserve buds in the stem, mature individuals of the Rhizophoraceae (Rhizophora and Ceriops) hold reserve buds only in the thin terminal twigs and "conditions severe enough to remove or kill all branches possessing viable reserve buds will potentially eliminate Rhizophora" (Hutchings and Saenger 1987). This implies that specific management principles need to be developed while harvesting different species to ensure that the diversity of the forest is maintained and gap recovery is fast enough to minimise gap sizes. 


\section{Conclusion}

The mangroves of Tudor creek, though stressed, are not irreversibly degraded. However, stand densities and basal areas were lower than for Rhizophoraceae dominated forests along the Kenyan coast (Gazi bay, 8-24 $\mathrm{m}^{2}$ ha $^{-1}, 1,130-2,571$ stems ha $^{-1}$; Kairo 2001; Bosire et al. 2003; Mida creek and Ngomeni, 24.05$46.97 \mathrm{~m}^{2} \mathrm{ha}^{-1}, 2,075-2,142$ stems ha $^{-1}$ : Kairo et al. 2002; Bundotich 2007). Globally, the values are in the middle of the reported range for similar forests (322-2,470 stems ha ${ }^{-1}$; Lugo and Snedaker 1973; Paijmans and Rollet 1977; Jimenez et al. 1985; Smith 1988). Within Mombasa, natural disturbances are either relatively small or rare, leaving anthropogenic disturbances the principal threat, thus management ought to focus on the anthropogenic element. Harvesting should be regulated through zoning of the forest coupled with a harvesting regime that includes replanting and closed periods, allowing for forest regeneration and growth. This will regulate canopy gap sizes, as intermediate level of gap creation may be optimal for long-term stand stability (Duke 2001).

To add value to peri-urban mangroves, management for multiple uses as opposed to single (forestry) products (Rönnbäck 1999; Barbier 2000; Ellison 2008; Nagelkerken et al. 2008), is desirable. Thus, in addition to meeting the wood demands of local populations, 'environmental' forests as no cut zones should be established for protection of migratory birds and other fauna for eco-tourism and subsistence, coupled with an integrated land use plan, which shall regulate causes of pollution and siltation and involve local communities in management. This will serve to boost the ecosystem resilience in the long-run.

Acknowledgements We express our appreciation to the local communities for their support in the sampling campaigns, and colleagues at KMFRI and KWS Coast Region Research station. The work described in this paper was supported by a PhD. Scholarship from the Flemish Interuniversity Council (VLIR) in Belgium and the EU funded PUMPSEA project (FP6-INCO contract no. 510863).

\section{References}

Abuodha PAW, Kairo JG (2001) Human-induced stresses on mangrove swamps along the Kenyan coast. Hydrobiologia 458:255-265
Allen JA, Ewel KC, Jack J (2001) Patterns of natural and anthropogenic disturbance of the mangroves on the Pacific island of Kosrae. Wetlands Ecol Manage 9:279-289

Alongi DM (2002) Present state and future of the world's mangrove forests. Environ Conserv 29(3):331-349

Alongi DM, de Carvalho NA (2008) The effect of small-scale logging on stand characteristics and soil biogeochemistry in mangrove forests of Timor Leste. For Ecol Manage 255:1359-1366

Barbier EB (2000) Valuing the environment as input: review of applications to mangrove-fishery linkages. Ecol Econ 35:47-61

Benfield SL, Guzman HM, Mair JM (2005) Temporal mangrove dynamics in relation to coastal development in Pacific Panama. J Environ Manage 76:263-276

Boonsong K, Plyatiratitivorakul S, Patanapompalboon $\mathrm{P}$ (2003) Potential use of mangrove plantation as constructed wetland for municipal wastewater treatment. Water Sci Technol 48(5):257-266

Bosire JO, Dahdouh-Guebas F, Kairo JG, Koedam N (2003) Colonization of non-planted mangrove species into restored mangrove stands in Gazi bay, Kenya. Aquat Bot 76:267-279

Bosire JO, Kairo JG, Kazungu J, Koedam N, Dahdouh-Guebas F (2005) Predation on propagules regulates regeneration in a high-density reforested mangrove plantation. Mar Ecol Prog Ser 299:149-155

Brokaw N, Thompson J (2000) The H for DBH. For Ecol Manage 129:89-91

Bundotich G (2007) Structural inventory of mangrove forests in Ngomeni, Kenya. MSc Thesis, Egerton University

Cannicci S, Burrows D, Fratini S, Lee SY, Smith TJ III, Offenberg J, Dahdouh-Guebas F (2008) Faunistic impact on vegetation structure and ecosystem function in mangrove forests: a review. Aquat Bot 89(2):186-200

Chong PW (1988) Proposed integrated forest management planning and utilization of mangrove resources in the Terraba-Sierpe Reserve, Costa Rica, TCP. FAO, Rome

Cintrón C, Schaeffer-Novelli Y (1984) Methods for studying mangrove structure. In: Snadaker SC, Snaedaker JG (eds) The mangrove ecosystem research methods. UNESCO, Paris, France, pp 91-113

Clarke PJ (2004) Effects of experimental canopy gaps on mangrove recruitment: lack of habitats partitioning may explain stand dominance. J Ecol 92:203-213

Clarke PJ, Kerrigan RA (2000) Do forest gaps influence the population structure and species composition of mangrove stands in Northern Australia? Biotropica 32(4a):642-652

Clarke PJ, Kerrigan RA (2002) The effects of seed predators on the recruitment of mangroves. J Ecol 90(4):728-736

Clutter JL, Fortson JC, Pienaar LV, Brister GH, Bailey RL (1983) Timber management: a quantitative approach. Wiley and Sons, $333 \mathrm{pp}$

Dahdouh-Guebas F, Koedam N (2006a) Empirical estimate of the reliability of the use of the Point-Centred Quarter Method (PCQM): solutions to ambiguous field situations and description of the PCQM protocol. For Ecol Manage 228:1-18

Dahdouh-Guebas F, Koedam N (2006b) Coastal vegetation and the Asian tsunami. Science 311:37-38 
Dahdouh-Guebas F, Koedam N (2008) Long-term retrospection on mangrove development using transdisciplinary approaches: a review. Aquat Bot. doi:10.1016/j.aquabot. 2008.03.012

Dahdouh-Guebas F, Mathenge C, Kairo JG, Koedam N (2000) Utilisation of mangrove wood products around Mida creek (Kenya) among subsistence and commercial users. Econ Bot 54(4):513-527

Dahdouh-Guebas F, Van Pottelbergh I, Kairo JG, Cannicci S, Koedam N (2004) Human-impacted mangroves in Gazi (Kenya): predicting future vegetation based on retrospective remote sensing, social surveys, and distribution of trees. Mar Ecol Prog Ser 272:77-92

Dahdouh-Guebas F, Hettiarachchi S, Lo Seen D, Batelaan O, Sooriyarachchi S, Jayatissa LP, Koedam N (2005) Transitions in ancient inland freshwater resource management in Sri Lanka affect biota and human populations in and around coastal lagoons. Curr Biol 15:579-586

Doute RN, Ochanda N, Epp H (1981) A forest inventory using remote sensing techniques. KREMU, Technological Report, Series No. 10. Rangeland Monitoring Unit, Nairobi, Kenya

Duke N (2001) Gap creation and regenerative processes driving diversity and structure of mangrove ecosystems. Wetlands Ecol Manage 9:257-269

Duke NC, Meynecke J-O, Dittmann S, Ellison AM, Anger K, Berger U, Cannicci S, Diele K, Ewel KC, Field CD, Koedam N, Lee SY, Marchand C, Nordhaus I, DahdouhGuebas F (2007) A world mangroves? Science 317:41-42

Ellis WL, Bell SS (2004) Canopy gaps formed by mangrove trimming: an experimental test of impact on litter fall and standing litter stock in Southwest Florida (USA). J Exp Mar Biol Ecol 311:201-222

Ellison AM (1998) Impacts of sediment burial on mangroves. Mar Pollut Bull 37(8-12):420-426

Ellison AM (2008) Managing mangroves with benthic biodiversity in mind: moving beyond roving banditry. J Sea Res 59(1-2):2-15

Ewel KC, Zheng S, Pinzon ZS, Bourgeois JA (1998) Environmental effects of canopy gap formation in high-rainfall mangrove forests. Biotropica 30(4):510-518

FAO (1994) Mangrove forest management guidelines. FAO Forestry Paper 117, Rome, 320 pp

FAO (2003) New global mangrove estimate. http://www.fao. org/forestry/foris/webview/forestry2/index.jsp\%3Fgeold= $0 \%$ 26langid

FAO (2005) Global forest resource assessment: progress towards sustainable forest management. FAO Forestry Paper 147, Rome, 348 pp

Feller IC, Whigham DF, McKee KL, Lovelock CE (2003) Nitrogen limitation of growth and nutrient dynamics in a disturbed mangrove forest, Indian River Lagoon, Florida. Oecologia 134:405-414

Ferguson W (1993) A land(scape) ecological survey of the mangrove resource of Kenya (Draft Report). Technical Cooperation Project (FAO TCP/KEN/OO51) for the Forestry Department, Ministry of Environment and Natural Resources, Nairobi, Kenya

Flower J, Imbert D (2006) Recovery deficiency following tree mortality in mangroves of two Caribbean islands: field survey and statistical classification. Wetlands Ecol Manage 14:185-199
Forest Department of Kenya (1983) Operational cruise reports on Lamu mangroves. Forest Department, Inventory Section, Nairobi, Kenya, 114 pp

Gang PO, Agatsiva JL (1992) The current status of mangroves along the Kenyan coast: a case study of Mida creek mangroves based on remote sensing. Hydrobiologia 247:29-36

Gilman EL, Ellison J, Duke NC, Field C (2008) Threats to mangroves from climate change and adaptation options: a review. Aquat Bot 89(2):237-250

GOK (2005) MOMBASA District Strategic Plan 2005-2010 for implementation of the national population policy for sustainable development. National Coordinating Agency for Population and Development, p 57

Greig-Smith P (1983) Quantitative plant ecology, 3rd edn. Blackwell Scientific Publications, 359 pp

Holdridge LR, Grenke WC, Hatheway WH, Liang T, Tosi JA (1971) Forest environment in tropical life zones. Pergamon Press, NY, 747 pp

Hutchings PA, Saenger P (1987) Ecology of mangroves. University of Queensland Press, St. Lucia, Queensland

Imai N, Takyu M, Nakamura Y, Nakamura T (2006) Gap formation and regeneration of tropical mangrove forests in Ranong, Thailand. Plant Ecol 186:37-46

Jimenez JA, Lugo AE, Cintron G (1985) Tree mortality in mangrove forests. Biotropica 17:177-185

Kairo JG (2001) Ecology and restoration of mangrove systems in Kenya. Laboratory of General Botany and Nature Management (APNA), Free University of Brussels, Belgium

Kairo JG, Dahdouh-Guebas F, Bosire J, Koedam N (2001) Restoration and management of mangrove systems-a lesson for and from the East African region. S Afr J Bot 67:383-389

Kairo JG, Dahdouh-Guebas F, Gwada PO, Ochieng C, Koedam N (2002a) Regeneration status of mangrove forests in Mida creek: a compromised or secured future? Ambio 31:7-8

Kairo JG, Kivyatu B, Koedam N (2002b) Application of remote sensing and GIS in the management of mangrove forests within and adjacent to Kiunga Marine Protected Area, Lamu, Kenya. Environ Dev Sustain 4(2):153-166

Kairo JG, Bosire J, Mohamed OS (2005) Assessment of the effects of oil spill on the mangrove forests of Port Reitz, Mombasa. Kenya Marine and Fisheries Research Institute. Mangrove System Information Service, Mombasa

Kokwaro JO (1985) The distribution and economic importance of the mangrove forests of Kenya. J East Afr Nat Hist Soc 75:1-10

Kristensen E, Bouillon S, Dittmar T, Marchand C (2008) Organic carbon dynamics in mangrove ecosystems: a review. Aquat Bot 89(2):201-219

López-Hoffman L, Ackerly DD, Anten NPR, Denoyer JL, Martinez-Ramos M (2007) Gap-dependence in mangrove life-history strategies: a consideration of the entire life cycle and patch dynamics. J Ecol 95(6):1222-1233

Lugo AE, Snedaker SC (1973) The role of mangrove ecosystems: properties of a mangrove forest in south Florida. National Technical Information Service, U.S. Department of Commerce, Springfield, Virginia (Final Report. No. DISFEP-74-73) 
Lugo AE, Snedaker SC (1974) The ecology of mangroves. Annu Rev Ecol Syst 5:39-64

Mandura AS (1997) A mangrove stand under sewage pollution stress: Red Sea. Mangrove Salt Marshes 1:255-262

Minchinton TE (2001) Canopy and substratum heterogeneity influence recruitment of the mangrove Avicennia marina. J Ecol 89:888-902

Morisita M (1959) Measuring of the dispersion of individuals and analysis of the distribution patterns. Mem Fac Sci Kyushu Univ Ser E Biol 2:215-235

Mueller-Dombois D, Ellenberg H (1974) Aims and methods of vegetation ecology. Wiley and Sons Inc., New York, USA

Munga D, Yobe AC, Owili M, Mwaguni SM (1993) Assessment of land based sources of pollution along the Kenyan coast. Report prepared for the WHO, Kenya Marine and Fisheries Research Institute, Kenya

Mwaguni S, Munga D (1997) Land based sources and activities affecting the quality and uses of the marine coastal and associated freshwater environments along the Kenya coast. Coastal Development Authority, Mombasa

Mwangi S, Kirugara D, Osore M, Njoya J, Yobe A, Dzeha T (1999) Status of marine pollution in Mombasa Marine Park and Reserve and Mtwapa creek. A technical report. Kenya Marine and Fisheries Research Institute, Government Chemist Department, Kenya Wildlife Service

Nagelkerken I, Blaber S, Bouillon S, Green P, Haywood M, Kirton LG, Meynecke J-O, Pawlik J, Penrose HM, Sasekumar A, Somerfield PJ (2008) The habitat function of mangroves for terrestrial and marina fauna: a review. Aquat Bot 89(2):155-185

Nguli MM (2006) Water exchange and circulation in selected Kenyan creeks. PhD. Dissertation, Earth Science Centre, Goteborg University, C78 2006

Osborne K, Smith TJ III (1990) Differential predation on mangrove propagules in open and closed canopy forest habitats. Vegetatio 89:1-6

Paijmans K, Rollet B (1977) The mangroves of Galley Reach, Papua New Guinea. For Ecol Manage 1:119-140

Pinzón ZS, Ewel KC, Putz FE (2003) Gap formation and forest regeneration in a Micronesian mangrove forest. J Trop Ecol 19:143-153

Primavera JH (1995) Mangroves and brackish water pond culture in the Philippines. Hydrobiologia 295:303-309

Rawlins P (1957) The East African mangrove trade. Unpublished typescript in the East African Herbarium, Nairobi, $30 \mathrm{pp}$

Rees JG, Williams TM, Nguli MM, Kairu KK, Yobe AC (1996) Contaminant transport and storage in the estuarine creek systems of Mombasa, Kenya. British Geological Survey Technical Report WC/96/42

Rönnbäck P (1999) The ecological basis for economic value of seafood production supported by mangrove ecosystems. Ecol Econ 29:235-52

Saenger P, Hegerl EJ, Davie JDS (1983) Global status of mangrove ecosystems. The Environmentalist 3(Suppl 3): 88
Sheppard C (2001) The main issues affecting the coasts of the Indian and western Pacific oceans: a meta-analysis from seas at the millennium. Mar Pollut Bull 42(12):1199-1207

Smith TJ III (1988) The influence of seed predators on structure and succession in tropical tidal forests. Proc Ecol Soc Aust 15:203-211

Snedaker SC, Brown MS, Lahmann EJ, Araujo RJ (1992) Recovery of a mixed-species mangrove forest in SouthFlorida following canopy removal. J Coastal Res 8(4): 919-925

Spalding M, Blasco F, Field C (1997) World Mangrove Atlas. International Society for Mangrove Ecosystems, Okinawa, Japan

SPEK (1992) Mangrove forest of Mombasa. Technical Report by Society for Protection of Environment, Kenya

Sukardjo S (1987) Natural regeneration status of commercial mangrove species (Rhizophora apiculata and Bruguiera gymnorhiza) in mangrove forests of Tanjung Bungin, Bunyuasin District, South Sumatra. For Ecol Manage 20:233-252

Taylor M, Ravilious C, Green EP (2003) Mangroves of East Africa. UNEP-WCMC Biodiversity Series No. 13

Terchunian A, Klemas V, Alvarez A, Vasconez B, Guerrero L (1986) Mangrove mapping in Ecuador: the impact of shrimp pond construction. Environ Manage 10:345-350

Thampanya U, Vermaat JE, Terrados J (2002) The effect of increasing sediment accretion on the seedlings of three common Thai mangrove species. Aquat Bot 74:315-325

Twilley RR, Snedaker SC, Yañez-Arancibia A, Medina E (1995) Biodiversity and ecosystem functioning: ecosystem analysis. Mangrove systems. In: Heywood VH (ed) Global biodiversity assessment, UNEP. Cambridge University Press, Cambridge, pp 387-392

Vaiphasa C, de Boer WF, Skidmore AK, Panit-chart S, Vaiphasa T, Bamrongrugsa N, Santitamnont P (2007) Impact of solid shrimp pond waste materials on mangrove growth and mortality: a case study from Pak Phanang, Thailand. Hydrobiologia 591:47-57

Valiela I, Bowen JL, York JK (2001) Mangrove forests: one of the world's threatened major tropical environments. Bioscience 51(10):807-815

Walters BB, Rönnbäck P, Kovacs J, Crona B, Hussain S, Badola R, Primavera JH, Barbier EB, Dahdouh-Guebas F (2008) Ethnobiology, socio-economics and adaptive management of mangroves: a review. Aquat Bot 89(2):220-236

Wong YS, Tam NFY, Lan CY (1997) Mangrove wetlands as wastewater treatment facility: a field trial. Hydrobiologia 352:49-59

World Resources Institute (1996) World Resources 1996-97. The World Resources Institute, UNEP, UNDP, World Bank. Oxford University Press, Oxford, p 365 